\title{
Benzo[a]pyrene and Caenorhabditis elegans: defining the genotoxic potential in an organism lacking the classical CYP1A1 pathway
}

\author{
Mustafa Abbass $^{1} \cdot$ Yuzhi Chen $^{1} \cdot$ Volker M. Arlt $^{1,2} \cdot$ Stephen R. Stürzenbaum $^{1}$ (D)
}

Received: 21 July 2020 / Accepted: 22 December 2020 / Published online: 9 January 2021

(C) The Author(s) 2021

\begin{abstract}
Benzo $[a]$ pyrene $(\mathrm{BaP})$ is bioactivated in most organisms by the cytochrome P450 (CYP) enzymes, mainly CYP1A1, ultimately resulting in the reactive metabolite $\mathrm{BaP}-7,8$-dihydrodiol-9,10-epoxide (BPDE) capable of covalently binding to DNA and forming adducts. This step has been defined as the key process in cancer initiation in humans. However, limited knowledge is available about the consequences of $\mathrm{BaP}$ exposure in organisms lacking this classical CYP1A1 pathway, one example is the model nematode Caenorhabditis elegans. The aim of this study was to define the genotoxic potential of BaP in C. elegans and to advance our understanding of xenobiotic processing in the absence of the CYP1A1 pathway. Exposure to high concentrations of $\mathrm{BaP}(0-40 \mu \mathrm{M})$ significantly affected life cycle endpoints of $C$. elegans, which were manifested by a reduced reproductive output and shortened life span. An optimised comet assay revealed that DNA damage increased in a dose-dependent manner; however, no bulky DNA adducts (dG- $N^{2}$-BPDE) were observed by ${ }^{32} \mathrm{P}$-postlabelling. Global transcriptomic analysis by RNA-Seq identified responsive transcript families, most prominently members of the cyp-35 and UDP-glucuronosyltransferases (UGTs) enzyme families, both of which are linked to xenobiotic metabolism. Strains harbouring mutations in the cyp-35A2 and cyp-35A3 genes were notably less prone to BaP-mediated toxicity, and BaP led to longevity in cyp-35A5 mutants. In summary, BaP induces transcriptional, genotoxic and phenotypic responses in C. elegans, despite the absence of the classical CYP1A1 bioactivation pathway. This provides first evidence that parallel pathways are implicated in BaP metabolism in C. elegans and this seems to be mediated via the cyp-35 pathway.
\end{abstract}

Keywords Caenorhabditis elegans $\cdot$ Benzo $[a]$ pyrene $\cdot$ DNA adducts $\cdot$ Xenobiotics

Mustafa Abbass and Yuzhi Chen have contributed equally to this work.

Supplementary Information The online version contains supplementary material available at https://doi.org/10.1007/s0020 4-020-02968-z.

Stephen R. Stürzenbaum stephen.sturzenbaum@kcl.ac.uk

1 Department of Analytical, Environmental and Forensic Sciences, School of Population Health and Environmental Sciences, Faculty of Life Sciences and Medicine, King's College London, London, UK

2 Present Address: Toxicology Department, GAB Consulting GmbH, 69126 Heidelberg, Germany

\section{Introduction}

Polycyclic aromatic hydrocarbons (PAHs) are products of the incomplete combustion of organic matter which are present in polluted air, diesel engine exhaust and tobacco smoke (Phillips 1999). Benzo[a]pyrene (BaP) is classified as Group 1 human carcinogen by IARC, because it can induce DNA damage and mutations in growth-controlling genes such as tumour suppressors or oncogenes leading to tumour development (IARC 2010). BaP has been extensively studied and is often used as a model PAH to define the underlying mechanisms linked to PAH carcinogenesis (Kasala et al. 2015). As a pro-carcinogen, $\mathrm{BaP}$ requires bioactivation by members of the cytochrome P450 (CYP) superfamily, which entail many haem-containing mono-oxygenases. In humans and rodents, $\mathrm{BaP}$ is first oxidised predominantly by CYP1A1 to BaP-7,8-epoxide, which is converted by microsomal epoxide hydrolase to BaP-7,8-dihydrodiol. Further activation by CYP1A1 leads to BaP-7,8-dihydrodiol-9,10-epoxide 
(BPDE) which can form pre-mutagenic adducts by covalently binding to DNA (Arlt et al. 2008; Alexandrov et al. 2016; Kucab et al. 2019). BPDE mainly react with purine bases in DNA, with 10-(deoxyguanosin- $N^{2}$-yl)-7,8,9-trihydroxy-7,8,9,10-tetrahydro-BaP (dG- $N^{2}$-BPDE) being the most abundant DNA adduct detected in mammalian DNA (IARC 2012). Additionally, BaP can produce depurinating adducts by metabolite (e.g., ortho-quinones, benzylic sulphate esters, and radical cations) interactions with the N7 positions of purine bases which consequently lead to the generation of apurinic sites inside the sugar phosphate backbone of DNA (Rogan et al. 1993; Casale et al. 2001; Chiang and Means 2008). BaP can generate reactive oxygen species (ROS) indirectly (through the activity of redox metabolites) that can also damage the DNA by producing lesions (e.g., 9-OH- dG), propene adducts, or DNA single-strand breaks (Harvey et al. 2005). The BaP mediated genotoxic pathway has been studied in fine detail in higher eukaryotes and involves the intricate processing via CYP1 enzymes (CYP1A1, CYP1B1, and CYP1A2) (Shimada et al. 1997; Gotoh 1998; Xue and Warshawsky 2005; Shimada 2006; Luch and Baird 2010). There is evidence that members of the less-known CYP2 sub- family (e.g., CYP2C8, CYP2C9, CYP2C18, and CYP2C19) are also capable of metabolizing BaP (Guengerich and Shimada 1992; Bauer et al. 1995; Šulc et al. 2016). Indeed, many studies have demonstrated that the human exposure to PAHs (including $\mathrm{BaP}$ ) results in the formation of DNA adducts (Albert et al. 1991; Harvey et al. 2005; Reed et al. 2018; Willis et al. 2018). A widely used and efficient technique in identifying DNA adducts induced by $\mathrm{BaP}$ (mainly the dG- $N^{2}$-BPDE) is the thin-layer chromatography ${ }^{32}$ P-postlabelling (Phillips and Arlt 2007, 2020).

Caenorhabditis elegans is a non-parasitic nematode which lives within the interstitial water in the soil. Characterised by a fast generation time and large brood size (Riddle et al. 1997) and its completely sequenced and fully annotated genome, C. elegans has been subjected to many genetical and biochemical studies (Steinberg et al. 2008). Some $60-80 \%$ of genes within the worm genome are orthologous to their human counterparts (Lai et al. 2000; Kaletta and Hengartner 2006), for example 12 out of 17 signal transduction pathways are conserved between humans and C. elegans (NRC 2000). More importantly, $40 \%$ of human disease-associated genes are represented by orthologs in the C. elegans genome (Culetto 2000). C. elegans has been used in the discovery of pharmacological targets for human diseases and is gaining attention as a promising multicellular alternative for studying environmental pollutants at the molecular level as well as the level of whole organisms (Meier et al. 2014; Polak et al. 2014; Steinberg et al. 2008; Volkova et al. 2020). Previous toxicological research with C. elegans mainly focused on inorganic substances, such as heavy metals (Williams and Dusenbery 1990; Harada et al.
2007) or pesticides (Jones et al. 1996; Rajini et al. 2008). Only few studies have centred around PAHs or more specifically BaP. Life cycle assessment revealed that growth, reproduction and survival are impacted in C. elegans after BaP exposure (Sese et al. 2009). DNA damage, measured as DNA breaks, was also observed in BaP-exposed worms when using the alkaline version of the single cell electrophoresis assay (comet assay) (Imanikia et al. 2016).

The present study investigated phenotypical alterations, molecular genetic responses, and genotoxicity induction of nematodes exposed to the environmental carcinogen BaP. The $C$. elegans model is uniquely positioned as it lacks the classical CYP1A1 pathway and thus allows the investigation of alternative mechanisms that drive $\mathrm{BaP}$ (geno)toxicity.

\section{Materials and methods}

\section{Chemicals}

BaP (CAS number 50-32-8; purity $\geq 96 \%$; Sigma-Aldrich, USA) was dissolved in dimethyl sulfoxide (DMSO; SigmaAldrich) to make a $40 \mathrm{mM}$ stock solution.

\section{C. elegans strains and maintenance}

C. elegans strains were maintained at $20{ }^{\circ} \mathrm{C}$ on Nematode Growth Media (NGM) plates supplemented with Escherichia coli OP50 as the food source. The $C$. elegans wild-type $\mathrm{N} 2$ Bristol as well as the mutant strains RB1788 [genotype: C03G6.14, cyp-35A1 (ok2306) V.], VC743 [genotype: C03G6.15, cyp-35A2 ( $g k 326)$ V.], RB2046 [genotype: K09D9.2, cyp-35A3 (ok2709) V.], RB1613 [genotype: K07C6.5, cyp-35A5 (ok1985) V.] were obtained from the Caenorhabditis Genetics Center (CGC), University of Minnesota. For each assay, nematodes were age-synchronised using an alkaline hypochlorite treatment to isolate the eggs. Thereafter, eggs were allowed to hatch overnight in M9 solution and arrested at L1 stage. On the following day, age synchronous L1 worms were transferred to NGM plates and utilised for the assays.

\section{Exposure of C. elegans to BaP}

$\mathrm{BaP}$ exposures were achieved by mixing E. coli OP50 bacteria with the appropriate volume of $\mathrm{BaP}$ stock solution to reach the desired concentration $(0-40 \mu \mathrm{M})$ for testing. DMSO at a final concentration of $0.1 \%$ was used throughout (including untreated controls). Aliquots of bacteria and $\mathrm{BaP}$ mixture were seeded on NGM plates and incubated at room temperature for 2 days. Thereafter, L1-synchronised worms were plated on $90 \mathrm{~mm}$ petri dishes which contained 
the bacteria (a culture containing $\mathrm{BaP}$ or DMSO [controls]). Worms were incubated at $20{ }^{\circ} \mathrm{C}$ for $48 \mathrm{~h}$ to reach the $\mathrm{L} 4$ stage.

\section{Reproduction assay}

Twenty-four age-synchronised L4 nematodes grown on OP50-inoculated NGM plates, supplemented with different concentrations of $\mathrm{BaP}$, were individually transferred to 12-well OP50-inoculated NGM plates supplemented with corresponding $\mathrm{BaP}$ concentrations. Worms were transferred daily to the same well positions of new 12-well plates under the same conditions until egg laying ceased, typically within a 4-day period. One day after the eggs hatched, images of the individual wells were taken using a high-resolution camera, and the number of viable L1 larvae were counted daily over a 6-day period.

\section{Life span assay}

Age-synchronised L1 worms were seeded onto OP50-inoculated NGM plates supplemented with different $\mathrm{BaP}$ concentrations. After 2 days, when the worms reached L4 stage, 200-400 worms were transferred to new plates containing the same BaP concentration. After that, daily transfers of all worms were performed. The worm status was assessed while transferring with a sterile platinum wire, scoring the worms as alive, dead, or lost (censored). The data input was analysed and processed in GraphPad Prism (version 8.2.1) by the Kaplan-Meier method, where the median survival, in days, were compared.

\section{Comet assay}

The basic procedure described in this study is adopted from Imanikia et al. (2016). Modifications were made to increase the sensitivity and specificity by applying formamidopyrimidine DNA glycosylase (FPG) which is a base excision repair enzyme able to recognize and remove a wide range of oxidised purines from corresponding damaged DNA. After lysis of the cells, the microscope slides were incubated twice in FPG-buffer for $10 \mathrm{~min}$. Therefore, $45 \mu \mathrm{L}$ of 10,000 times diluted FPG enzyme (Sigma-Aldrich) was introduced to each slide and incubated in a humidity chamber at $37^{\circ} \mathrm{C}$ for $30 \mathrm{~min}$. Comets were analysed using a Leica fluorescence microscope (Leica DMLB 020-519-010 LB30T). DNA damage was scored using the Comet IV capture system (version 4.11; Perceptive Instruments, UK). Each technical replicate consisted of three slides in which fifty cell nucleoids were assessed per slide, and each sample was analysed in triplicate. All samples were scored blind. The tail intensity (\% tail DNA), defined as the percentage of DNA migrated from the head of the comet into the tail, was used as a measure of DNA damage induced.

\section{Genomic DNA extraction and ${ }^{32}$ P-postlabelling assay}

Age-synchronised L4 worms, grown under different $\mathrm{BaP}$ concentrations, were collected from plates with M9 buffer, serially washed with M9 buffer, mixed with sterile glass beads, and flash-frozen in liquid nitrogen. A $400 \mu \mathrm{L}$ mixture of ethylenediaminetetraacetic acid (EDTA, $1 \mathrm{mM}$ ) and tris(hydroxymethyl)aminomethane (Tris, $50 \mathrm{mM}$ ) was added to each tube before vertexing for $5 \mathrm{~min}$. Then, the supernatants were transferred to new $1.5-\mathrm{mL}$ microcentrifuge tubes, and $9 \mu \mathrm{L}$ of an RNase mixture of equal amounts of pancreatic ribonuclease (RNase A, $10 \mathrm{mg} / \mathrm{mL}$, Sigma-Aldrich) and ribonuclease T1 (RNase T1, $50 \mathrm{KU}$, Sigma-Aldrich) were added to the samples. The tubes were incubated on a shaker $(400 \mathrm{rpm})$ at $37{ }^{\circ} \mathrm{C}$ for $30 \mathrm{~min}$. Thereafter, $40 \mu \mathrm{L}$ of a freshly prepared proteinase $\mathrm{K}[10 \mathrm{mg} / \mathrm{mL}$ dissolved in a mix of EDTA $(1 \mathrm{mM})$ and Tris $(50 \mathrm{mM})]$ were added and mixed with the samples. The tubes were incubated on a shaker (400 rpm) at $37{ }^{\circ} \mathrm{C}$ overnight. The following day, DNA was isolated using a standard phenol-chloroform extraction method. DNA pellet was resuspended in TrisEDTA (TE) buffer were stored at $-20{ }^{\circ} \mathrm{C}$ until analysis. The presence of BaP-derived DNA adducts (dG- $N^{2}$-BPDE) was assessed using the nuclease $\mathrm{P} 1$ enrichment method of the ${ }^{32} \mathrm{P}$-postlabelling protocol as described previously (Arlt et al. 2008; Phillips and Arlt 2020).

\section{Total RNA extraction}

A minimum of 7000 synchronised L4 stage C. elegans were washed off from NGM plates and collected. Total RNA was extracted using Tri-reagent (Sigma-Aldrich, St. Louis, MO, USA) modified to include a homogenization of nematodes by vortexing with an equal quantity of acid-washed glass beads (particle size 425-600 $\mu \mathrm{m}$, Sigma-Aldrich). The concentration and integrity of total RNA was determined with a NanoDrop 1000 Spectrophotometer (NanoDrop Technologies, Inc., Wilmington, DE, USA) and by $2 \%$ agarose gel electrophoresis.

\section{RNA sequencing and data processing}

RNA was extracted from BaP-exposed L4 nematodes, frozen at $-80^{\circ} \mathrm{C}$. The RNA integrity number (RIN) for each sample was determined via the Agilent Technology 2100 Bioanalyzer system using an RNA 6000 Nano kit (Supplementary figures 1 and 2). RNA-seq libraries prepared by GENEWIZ $^{\mathrm{TM}}$ (Essex, UK) according to Illumina's instructions. Briefly, mRNAs were purified using Poly(A) selection 
from total RNA and then fragmented. First strand of cDNA was synthesised using random priming, followed by the synthesis of the second strand of cDNA. The resulting doublestrand cDNA was end repaired, phosphorylated and A-tailed. Adapter ligation and PCR amplification were performed, rendering the library ready for Illumina flow cell clustering and sequencing on an Illumina HiSeq 2500 to sequence tens of millions of sequence clusters in parallel (Bentley et al. 2008).

Sequence reads (at least 30 million per sample/replicate) were trimmed to remove possible adapter sequences, sequence reads shorter than 30 nucleotides and nucleotides with poor quality (error rate $<0.05$ ) were removed. The sequence reads were mapped to the $C$. elegans reference genome using the CLC Genomics Server program and the hit counts and RPKM values for genes calculated. After quantile normalization and log2-transformation on RKPM values, unsupervised hierarchical clustering and Principal Component Analysis (PCA) were performed. Comparisons of genes between various groups of samples were performed. A student $t$ test was conducted for each comparison after quantile normalization and $\log 2$-transformation. A gene was selected if the $p$ value was $<0.05$ and the fold-change of normalized RPKMs was $>2$. To analyse the variation of gene expression across the duplicates, the mean normalized RPKMs, standard deviation and coefficient of variation (CV) was calculated within each group.

\section{Real-time quantitative PCR}

cDNA was synthesized from 1000 ng RNA using an oligo dT primer $\left(5^{\prime}-(\mathrm{T})_{20} \mathrm{VN}-3^{\prime}\right)$ and M-MLV reverse transcriptase (Promega, Southampton, UK) applying standard incubation conditions. The transcript quantity was measured on an ABI Prism 7500 Fast (Applied Biosystems ${ }^{\circledR}$, Paisley, UK) using the housekeeping gene rla- 1 (acidic ribosomal subunit protein P1) for normalization purposes (Swain et al. 2004; Polak et al. 2014). All probes and primers were designed to be compatible with the Universal Probe Library (Roche Applied Sciences, Burgess Hill, UK) (Supplementary 3). The CT values were determined using the 7500 Fast System SDS Software (Applied Biosystems ${ }^{\circledR}$ ) and the fold changes in gene expression were calculated by applying the $2^{-\Delta \Delta \mathrm{Ct}}$ method. Statistical analysis was performed on three independent biological replicates, each consisting of three technical repeat measurements.

\section{Statistical analysis}

The analysis of variance (ANOVA) was employed to evaluate the majority of data in the study. $T$ tests were employed to scrutinize the variation significance between an exposure sample and a control. All statistical tests for this project were conducted using GraphPad Prism (version 8.2.1). Statistical significances throughout were indicated by asterisks; * for a $p$ value $\leq 0.05$, ** for a $p$ value $\leq 0.01, * * *$ for a $p$ value $\leq 0.001$, and $* * * *$ for a $p$ value $\leq 0.0001$.

\section{Results}

\section{Impact of BaP exposure on reproduction}

A key endpoint which evaluates toxicity of xenobiotics in C. elegans is brood size. Changes in reproductive output in BaP-exposed wild-type worms $(0-40 \mu \mathrm{M}$ from $\mathrm{L} 1$ to $\mathrm{L} 4$ stage) was assessed by counting the number of viable offspring during the egg laying period. The cumulative brood size was determined to be $223 \pm 12$ viable larvae in wild-type control (unexposed). In comparison, the cumulative average number of viable larvae decreased significantly with increasing $\mathrm{BaP}$ concentration, resulting in $176 \pm 11$ and $171 \pm 21$ offspring per worm exposed to 5 and $10 \mu \mathrm{M}$, respectively. For worms exposed to $20 \mu \mathrm{M} \mathrm{BaP}$, the reproductive output decreased to $134 \pm 20$. Exposure to $40 \mu \mathrm{M} \mathrm{BaP}$ for 6 days reduced the number of viable larvae to $129 \pm 13$ (Fig. 1a). During the first 3 days of egg laying, a significant decrease in the number of the viable larvae was observed in worms exposed to $20 \mu \mathrm{M}$ and $40 \mu \mathrm{M} \mathrm{BaP}$ in comparison with control (unexposed) worms.

\section{Impact of BaP exposure on life span}

The life span assay is used routinely to determine the effect of a xenobiotic chemical on aging and death (Koch et al. 2014). Age-synchronised L1 wild-type C. elegans were exposed to different concentrations of $\mathrm{BaP}(0-40 \mu \mathrm{M})$, transferred daily onto freshly prepared NGM plates with the same experimental conditions and the numbers of alive, dead, and censored worms were recorded. This was repeated until all worms of all groups died. The median survival (50\% alive) of wild-type control worms was determined to be 12 days which decreased by 1-2 days at concentrations of $\mathrm{BaP}$ above $1 \mu \mathrm{M} \mathrm{BaP}$, an effect which was statistically significant (Fig. 1b).

\section{Induction of DNA strand breaks (comet assay) after BaP exposure}

Wild-type nematodes were exposed to various concentrations of $\mathrm{BaP}(0,1,5,10,20$, and $40 \mu \mathrm{M})$ for $48 \mathrm{~h}$. Cells successfully isolated from these worms were then embedded onto pre-coated agarose slides. A portion of these slides was further incubated with FPG to measure oxidative damage to DNA. FPG is a base excision repair enzyme which recognises and removes a wide range of oxidised purines 


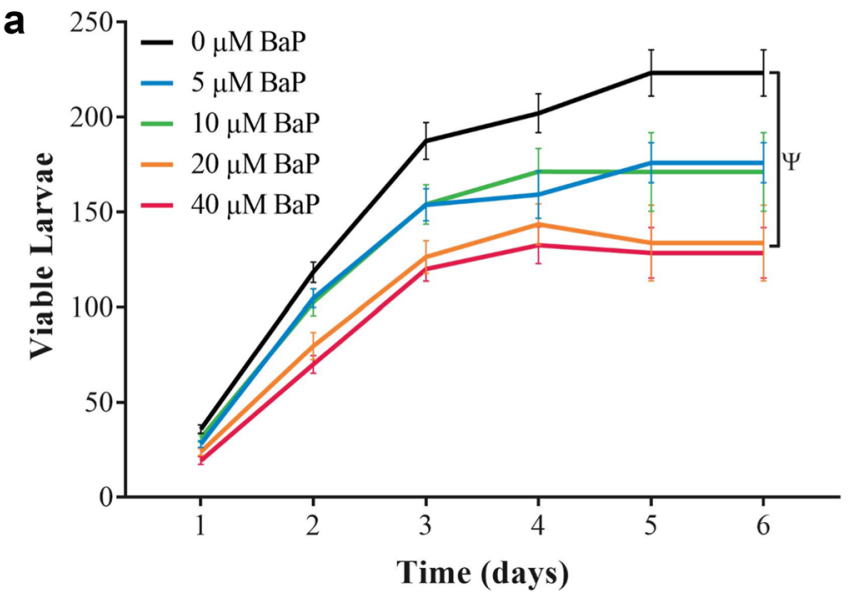

Fig. 1 a Wild-type C. elegans were exposed to $\mathrm{BaP}(0-40 \mu \mathrm{M})$ for 8 days, and the average daily number of viable larvae was counted every $24 \mathrm{~h}$ and cumulatively added during the egg laying phase (marked 1-6). Error bars represent SEM. Statistical analysis was performed using a two-way ANOVA, followed by a Tukey's multiple comparisons test, $n=24$ per $\mathrm{BaP}$ concentration. $\Psi=$ the $p$ value of 0 vs. $20 \mu \mathrm{M} \mathrm{BaP} \leq 0.01$, and of 0 vs. $40 \leq 0.001$. b The percentage survival of wild-type $C$. elegans exposed to different concentrations of $\mathrm{BaP}(0-40 \mu \mathrm{M})$. The worms were scored by transferring them all

from the corresponding damaged DNA. This additional step increases the sensitivity and specificity of the comet assay (Hansen et al. 2010). Afterwards, all the slides were run

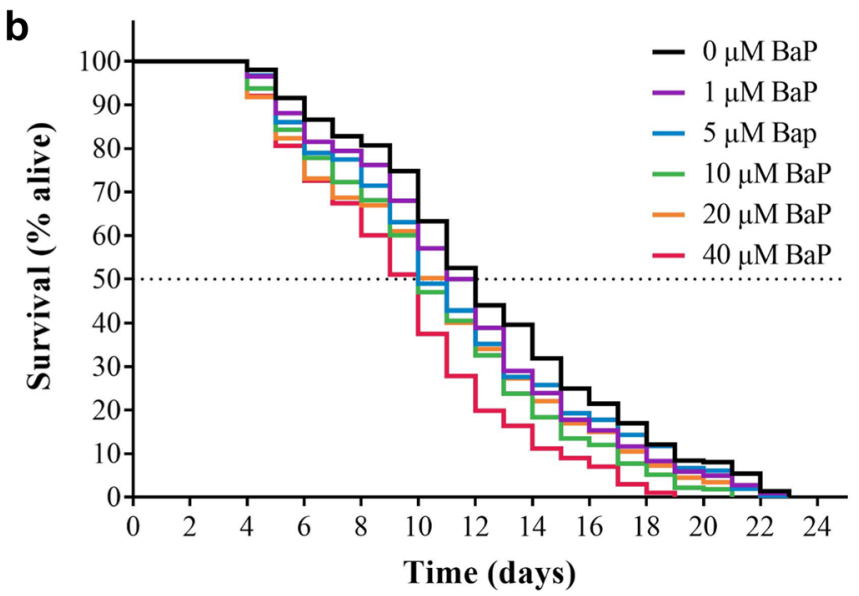

to a new plate every $24 \mathrm{~h}$ from L1 stage until all worms were dead. Lost or mistakenly killed worms were censored and removed from the data. Note that the median survival (50\% alive) of worms was measured to be 12 days for the control worms (BaP [0 $\mu \mathrm{M}$ ]; DMSO [0.1\% $\mathrm{v} / \mathrm{v}])$ but only 10 days for the highest $\mathrm{BaP}$ concentration $(40 \mu \mathrm{M})$. Statistical analysis was performed using log-rank (Mantel-Cox) test, $n=400$ per $\mathrm{BaP}$ concentration. All samples contained DMSO $(0.1 \%$ $\mathrm{v} / \mathrm{v})$

through a single-cell gel electrophoresis (comet assay) and DNA damage was scored using the Comet IV capture system (Fig. 2a). No inter-sample differences in atypical comets a

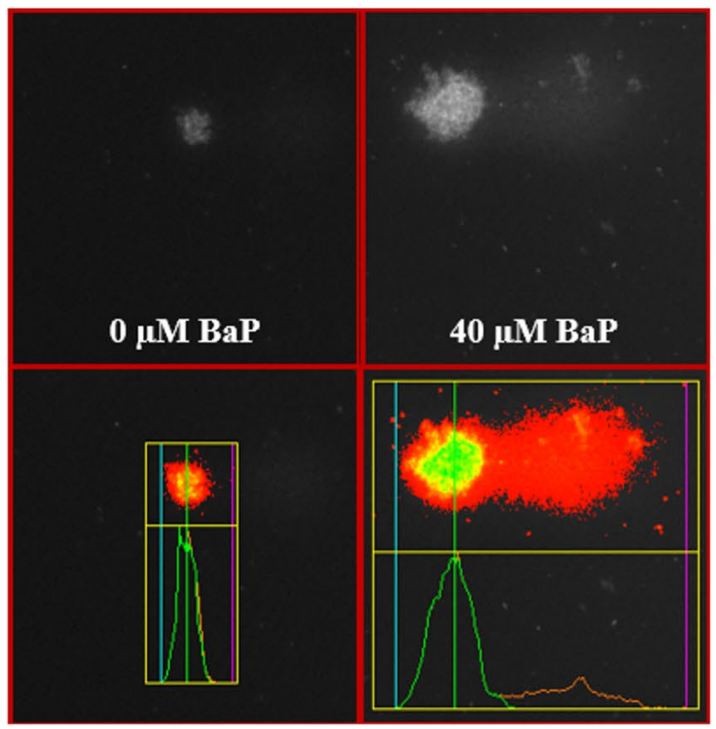

Fig. 2 a Images on the upper row are representative cells after performing the comet assay isolated from wild-type $C$. elegans exposed for $48 \mathrm{~h}$ to different $\mathrm{BaP}$ doses $(0,1,5,10,20$, or $40 \mu \mathrm{M})$. The images on the lower row are outputs from the Comet IV software (version 4.11, Perceptive Instruments Ltd., UK). b A box plot of the \% tail DNA in cells isolated from wild-type $C$. elegans exposed for $48 \mathrm{~h}$ to different doses of $\mathrm{BaP}(0,1,5,10,20$, or $40 \mu \mathrm{M})$ and treatment with FPG at 0 and $40 \mu \mathrm{M}$ BaP. Fifty cell nucleoids were measured

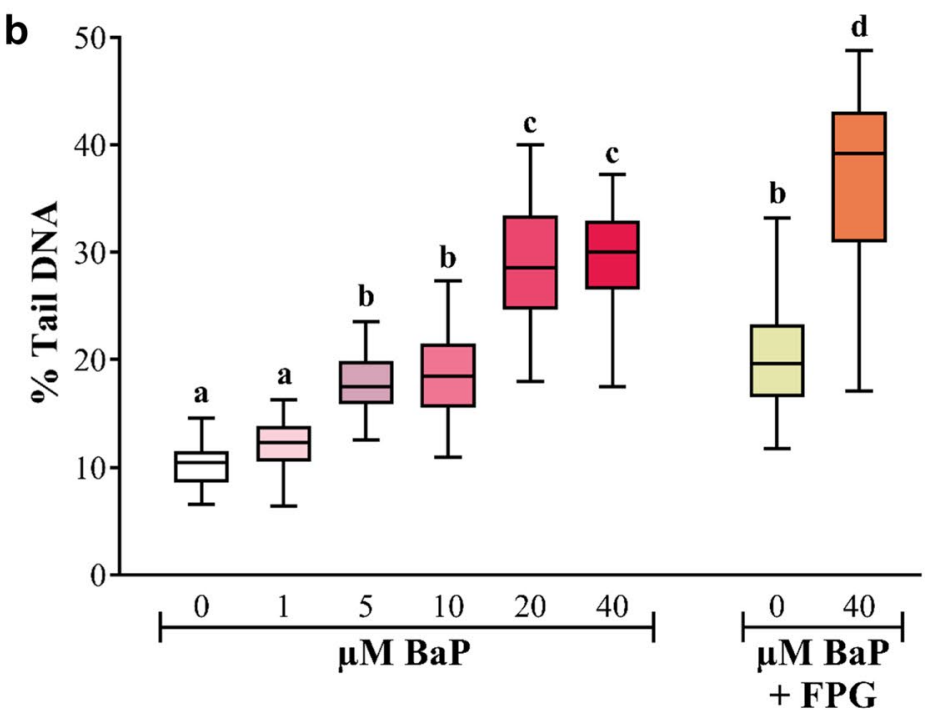

per slide (technical replicates), for a total of 150 cells per biological replicate ( 3 slides) and 450 total cells per experimental condition (3 biological replicates). The average of 150 cells was calculated for all biological replicates and then averaged $(n=3)$. Statistical analysis was performed using a one-way ANOVA, followed by a Tukey's multiple comparisons test; a, b, c, d refers to the calculated probability ( $p$ value), where different letter denote $p \leq 0.0001$. All samples contained DMSO $(0.1 \% \mathrm{v} / \mathrm{v})$ 
(e.g., hedgehogs) were noted; however, an increase in the tail intensity (\% tail DNA) was observed after exposure to increasing BaP concentrations. The baseline in control (unexposed) worms was about $10 \%$. After $\mathrm{BaP}$ exposure tail intensity increased to $\sim 17 \%$ in worms treated with 5 and $10 \mu \mathrm{M} \mathrm{BaP}$ and further increased up to $\sim 30 \%$ after treatment with 20 and $40 \mu \mathrm{M}$ BaP. When the FPG-modified comet assay was performed background DNA damage increased from 10 to $19 \%$ in controls (unexposed). Similarly, the $\%$ tail DNA generated from a comet assay on cells dissociated from nematodes exposed to $40 \mu \mathrm{M}$ BaP also increased by $\sim 9 \%$ when the comet assay was modified with FPG (from $~ 30 \%$ to $39 \%$ ) (Fig. 2b). No information was gathered regarding the viability of the cells used for the comet assay.

\section{DNA adduct formation after BaP exposure}

For DNA adduct analysis the ${ }^{32} \mathrm{P}$-postlabelling assay was performed (Phillips and Arlt 2020) which is capable of detecting BaP-derived DNA adducts (Arlt et al. 2008). As shown in Fig. 3a, using BaP-exposed mouse liver DNA as positive control, BaP exposure lead to one major DNA adduct spot on the thin-layer chromatography plate which was previously identified as $\mathrm{dG}-N^{2}$-BPDE (Arlt et al. 2008). In contrast, no BaP-derived DNA adducts (i.e., dG$N^{2}$-BPDE) were detected in wild-type $C$. elegans exposed to $20 \mu \mathrm{M}$ (Fig. 3b) and $40 \mu \mathrm{M}$ BaP for $48 \mathrm{~h}$. Nematodes

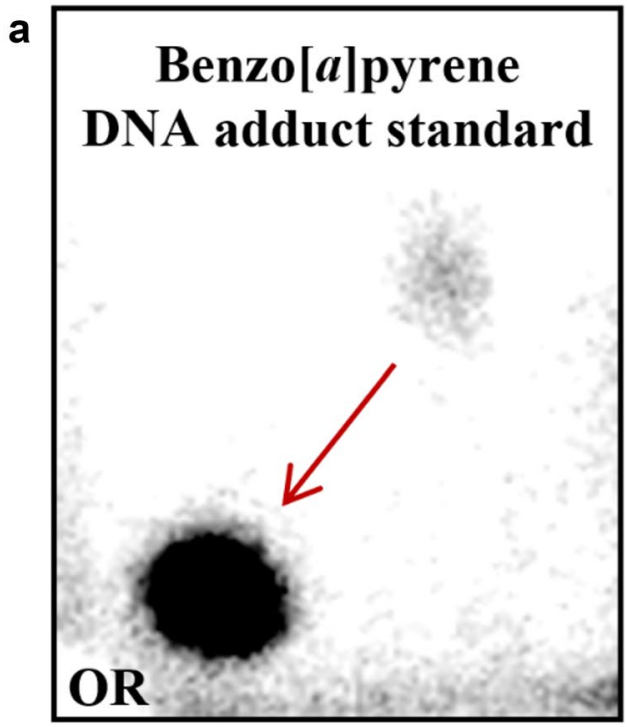

Fig. 3 Representative autoradiographic profiles of DNA adducts obtained by TLC ${ }^{32} \mathrm{P}$-postlabelling in wild-type $C$. elegans exposed to $20 \mu \mathrm{M} \mathrm{BaP}$ for $48 \mathrm{~h}$. a Liver DNA isolated from mice treated with a single intraperitoneal dose of $125 \mathrm{mg} / \mathrm{kg}$ body weight $\mathrm{BaP}$ was used as positive control (Arlt et al. 2012). b The arrow indicates the $\mathrm{dG}-N^{2}$-BPDE adduct. Solvent conditions for the separation of BaP- exposed to BaP were independently tested twice, Fig. 3 showing representative images.

\section{Transcriptional analysis}

A global RNA-seq transcriptomic experiment was investigated to provide an understanding of the underlying mechanisms by which BaP exerts its effects on the nematode. Principal component analysis (PCA) was performed using the ClustVisTM web tool (Metsalu and Vilo 2015) which illustrates the reproducible technical generation of samples (Supplementary Figures 4 and 5). Additional validation on 15 transcripts was performed by qPCR which confirmed that the overall trend in expression dynamics was comparable between RNA-seq and qPCR (Supplementary Figures 6 and 7). A distinct transcriptional response was observed, namely the expression of only 312 transcripts were significantly $(p \leq 0.05)$ and differentially (2-fold or higher) altered after $\mathrm{BaP}$ exposure to either 5 or $20 \mu \mathrm{M} \mathrm{BaP}$ in comparison to control (unexposed) (Fig. 4a). Many of the most significantly up-regulated transcripts were common in worms exposed to $5 \mu \mathrm{M}$ or $20 \mu \mathrm{M}$ BaP, with clear dose-dependent increase in expression levels (Table 1). In contrast, only four of the 177 significantly $(p \leq 0.05)$ down-regulated transcripts were common in worms exposed to 5 or $20 \mu \mathrm{M}$ BaP. No genes were up-regulated in samples exposed to $5 \mu \mathrm{M} \mathrm{BaP}$ and at the same time down-regulated in samples exposed to $20 \mu \mathrm{M}$ $\mathrm{BaP}$, nor vice versa (Fig. 4a).

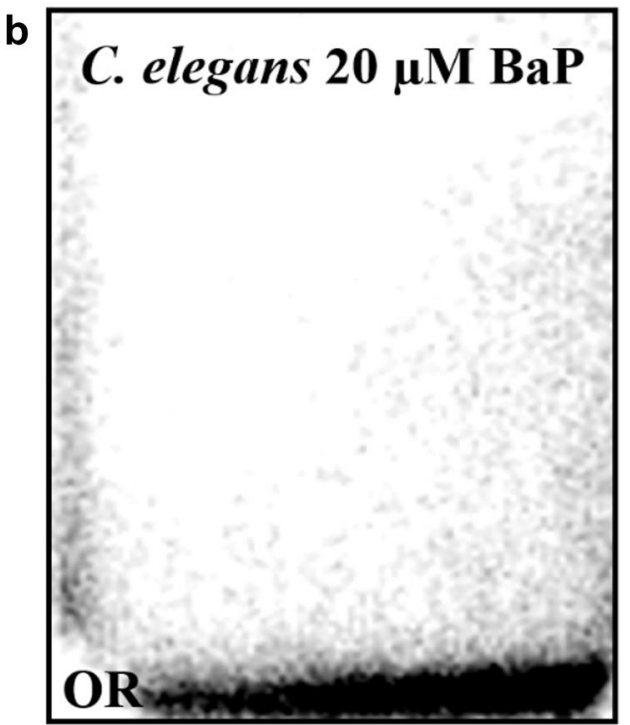

derived DNA adducts on PEI-cellulose TLC were as follows: D1, sodium phosphate $(1 \mathrm{M}), \mathrm{pH}=6.0 ; \mathrm{D} 3$, lithium formate $(3.5 \mathrm{M})$, urea (8.5 M), $\mathrm{pH}=3.5$; $\mathrm{D} 4$, lithium chloride $(0.8 \mathrm{M})$, Tris $(0.5 \mathrm{M})$, urea $(8.5 \mathrm{M}), \mathrm{pH}=8.0$. The origins $(\mathrm{OR})$, at the bottom left-hand corners, of each chromatogram were cut off before exposure 
a

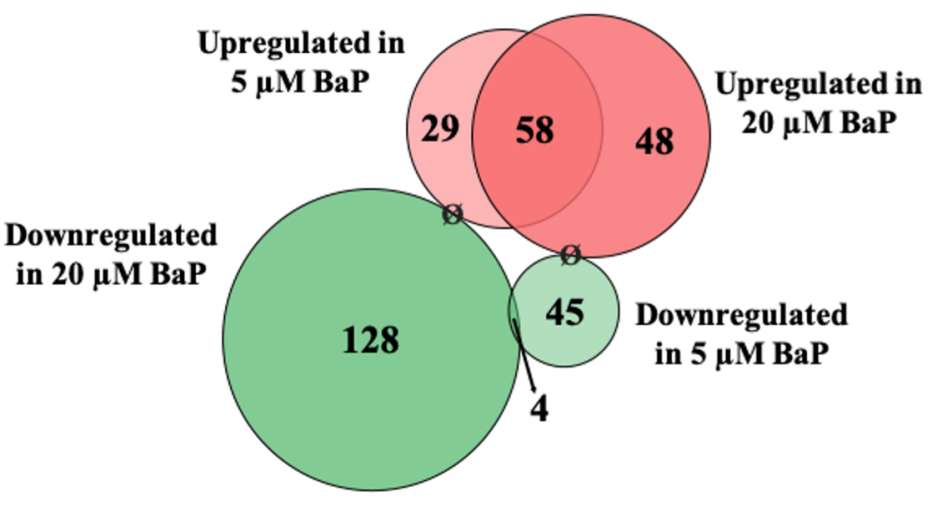

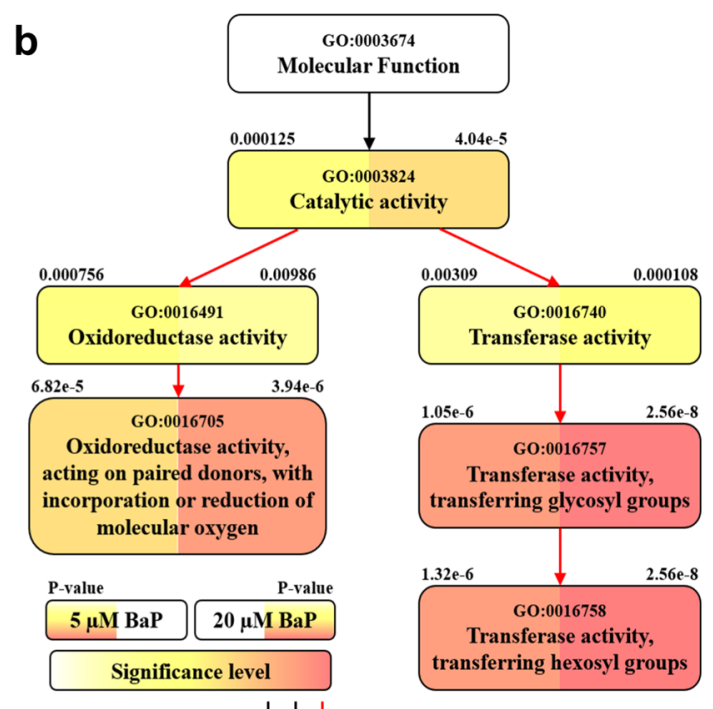

Enriched terms at both ends $\downarrow^{1} \downarrow_{1} \downarrow_{2}$
Fig. 4 a Proportionally sized Venn diagram showing the 312 significantly ( $t$ test, $p \leq 0.05, n=3$ ) and differentially regulated genes (>2-fold change) of wild-type $C$. elegans exposed to different doses of $\mathrm{BaP}(0,5$, or $20 \mu \mathrm{M})$ for $48 \mathrm{~h}$. Ø marks a zero gene overlap. b Partial gene ontology (GO) hierarchical tree presenting molecular functions which were found to be significantly enriched in wild-type C. elegans exposed to different concentrations of $\mathrm{BaP}(0$ vs. 5 and 0 vs. $20 \mu \mathrm{M}$ ) for $48 \mathrm{~h}$. Boxes on the graph represent GO terms labelled with their GO number, term definition, and statistical information ( $p$ value) on both sides on top of the boxes ( 5 and $20 \mu \mathrm{M} \mathrm{BaP}$ on

Two main gene groups were significantly altered after BaP exposure. Firstly, the cyp genes (especially the cyp35 family), which are linked to xenobiotic response, redox reactions, and lipid metabolism. Seven (of the 10) cyp-35 genes were represented in the list of the top $37 \mathrm{BaP}$ most highly induced genes ( 0 vs. $20 \mu \mathrm{M},>5$-fold induction, $t$ test, $p \leq 0.05, n=3$ ) (Table 2). Secondly, UDP-glucuronosyltransferase (UGT) genes, which are linked to the biotransformation of xenobiotics, including phase II metabolism of $\mathrm{BaP}$ in higher eukaryotes (Brand et al. 2010; Kurita et al. 2017). Nine (of 65) ugt genes were in the list of the top 37 BaP-induced genes ( 0 vs. $20 \mu \mathrm{M},>5$-fold induction, $t$ test, $p \leq 0.05, n=3$ ) (Table 3).

In addition to genes linked to $\mathrm{BaP}$ metabolism, based on the RNA-seq, two further groups of genes were significantly and differentially regulated, namely infection response and innate immune response genes such as F35E12.5 (irg-5), F08G5.6 (irg-4), C32H11.1 (irg-6) and C-type lectin (clec) genes. F35E12.5 (irg-5) was the most significantly up-regulated gene in the data set; it was induced $\sim 90$-fold at $5 \mu \mathrm{M}$ $\mathrm{BaP}$ and $\sim 270$ fold at $20 \mu \mathrm{M} \mathrm{BaP}$, respectively.

The most significant molecular functions (GO:0003674) obtained from the RNA-seq data set were the oxidoreductase activity, acting on paired donors, with incorporation or reduction of molecular oxygen (GO:0,016,705) the left and right side, respectively). The degree of colour saturation (from white through yellow to red) of one side of the box is positively correlated to the enrichment level of the term for that exposure condition. Black dashed, black solid, and red solid lines represent zero, one, and two enriched terms at both ends connected by a line. The graph was based on the results of DAVID Bioinformatics Resources version 6.8 and PANTHER classification version 14.0 and was constructed manually. All samples contained DMSO (0.1\% v/v) (colour figure online)

and transferase activity, transferring hexosyl groups (GO:0016758) (Supplementary 8). These are linked to the significantly ( $t$ test, $p \leq 0.05$ ) up-regulated $c y p$ genes (mainly the cyp-35's) and the large number of the significantly ( $t$ test, $p \leq 0.05$ ) up-regulated ugt genes, respectively (Fig. $4 \mathrm{~b}$ ).

\section{The CYP phylogenetic tree}

To investigate the relationship between human and C. elegans $\mathrm{BaP}$ metabolism, a phylogenetic tree was constructed consisting of the Homo sapiens CYPs implicated in the metabolism of BaP, CYP1A1, CYP1B1, and CYP1A2 (Shimada et al. 1997; Gotoh 1998; Xue and Warshawsky 2005; Shimada 2006; Luch and Baird 2010), CYP2s (Wang et al. 2017), and others (Prakash et al. 2015) as well as the 75 CYPs expressed in C. elegans. Based on sequence homology, the majority of the human and worm CYPs clustered, at large, distinctly separate, with the human CYP1s / CYP2Cs and the worm CYP-35's positioned within separate clades (Fig. 5). The H. sapiens CYP2Cs are located in neighbouring clades close to $C$. elegans CYP-33 s and CYP-14 s, with cyp-14A4 notably shown to be significant upregulated in worms exposed to BaP. C. elegans CYP-34A9, the other upregulated CYP in worms, is also positioned close to the CYP-35s family. An equivalent phylogenetic tree was 
Table 1 Top upregulated gene with their sequence names, their expression differences ( 0 vs. 5 and $20 \mu \mathrm{M} \mathrm{BaP})$, and their $t$ test $p$ values obtained from the RNA-seq data (0 vs. $20 \mu \mathrm{M}$ $\mathrm{BaP},>5$-fold change, $t$ test, $p \leq 0.05, n=3)$ in comparison to the control $(0 \mu \mathrm{M} \mathrm{BaP})$

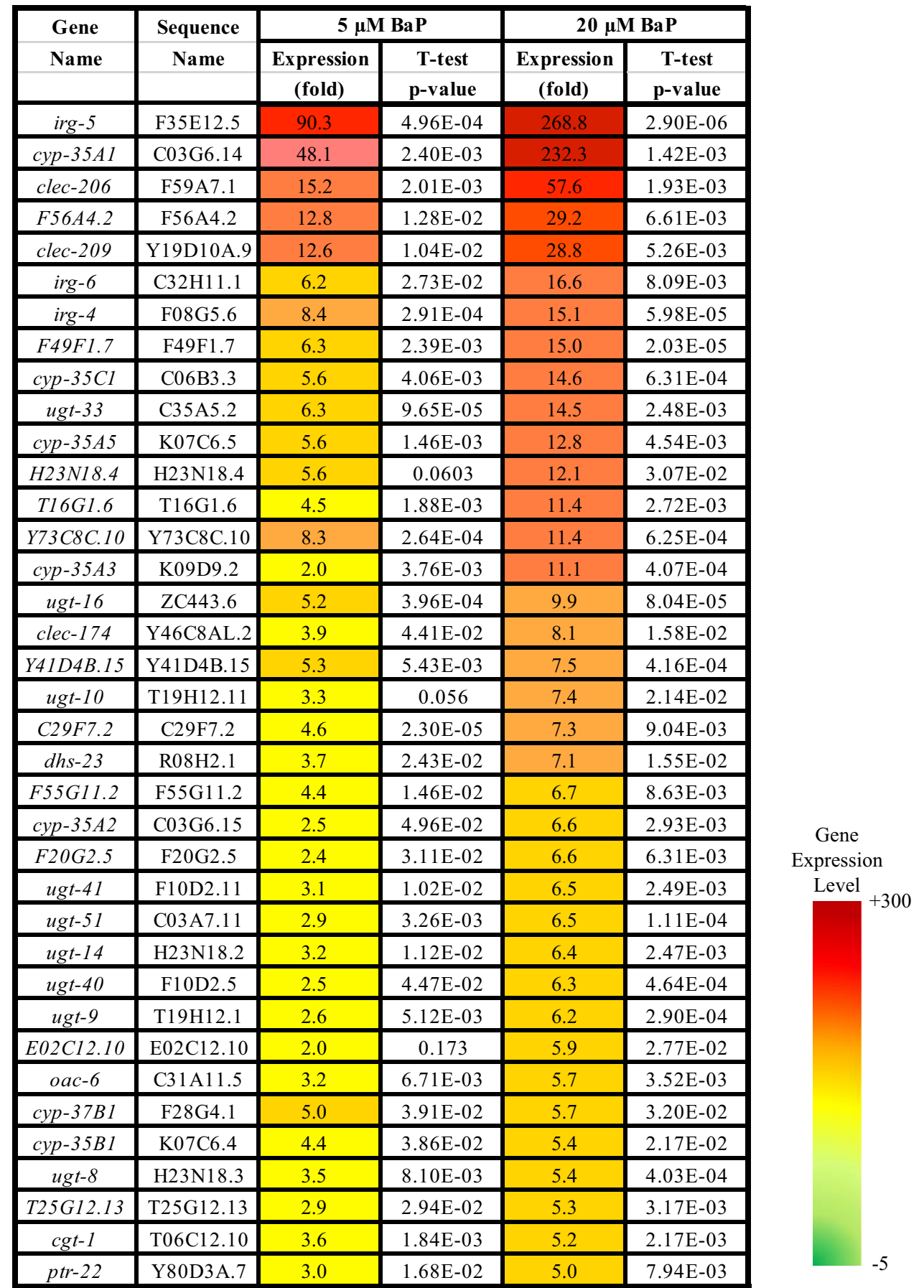

generated for UGTs, again suggesting that worm and mammalian UGT's differ, at least by sequence homology (Supplementary 9).

\section{The effect of BaP on knockout mutant strains}

Five cyp-35 genes (cyp-35A1, cyp-35A2, cyp-35A3, cyp$35 A 5$, and $c y p-35 B 1$ ), identified by RNA-Seq as key genes with possible links to xenobiotic exposure and metabolism, were selected to explore their involvement on $\mathrm{BaP}$ mediated changes in the physiological end points measurements. When cyp-35A2 KO worms were exposed to $40 \mu \mathrm{M} \mathrm{BaP}$, their average cumulative viable larvae count was significantly higher compared to wild-type nematodes exposed to the same BaP concentration (Fig. 6a, b). In addition, there was no significant change in the average cumulative number of viable larvae between control (unexposed) and BaP-exposed cyp-35A2 KO nematodes 
Table 2 List of all cyp-35 genes in wild-type C. elegans with their sequence names, their expression differences ( 0 vs. 5 and 0 vs. $20 \mu \mathrm{M} \mathrm{BaP}$ ), and their $t$ test $p$ values as obtained from the RNA-seq data $(t$ test, $p \leq 0.05)$. N/A $=$ not available

Table 3 List of all significantly and differentially regulated ugt genes, out of a total of 65 $u g t$ genes $(>2$-fold change, $t$ test, $p \leq 0.05, n=3$ ), with their sequence names, their expression differences ( 0 vs. 5 and 0 vs. $20 \mu \mathrm{M} \mathrm{BaP}$ ), and their $t$ test $p$ values, as obtained from the RNA-seq data

\begin{tabular}{|c|c|c|c|c|c|}
\hline \multirow{2}{*}{ Gene } & Sequence & \multicolumn{2}{|c|}{$\mathbf{5} \boldsymbol{\mu M}$ BaP } & \multicolumn{2}{c|}{$\mathbf{2 0} \boldsymbol{\mu M}$ BaP } \\
\cline { 3 - 6 } Name & Name & $\begin{array}{c}\text { Expression } \\
\text { (fold) }\end{array}$ & $\begin{array}{c}\text { T-test } \\
\text { p-value }\end{array}$ & $\begin{array}{c}\text { Expression } \\
\text { (fold) }\end{array}$ & $\begin{array}{c}\text { T-test } \\
\text { p-value }\end{array}$ \\
\hline cyp-35A1 & C03G6.14 & 48.1 & $2.40 \mathrm{E}-03$ & 232.3 & $1.42 \mathrm{E}-03$ \\
\hline$c y p-35 B 2$ & K07C6.3 & 69.9 & N/A & 71.1 & N/A \\
\hline$c y p-35 C 1$ & C06B3.3 & 5.6 & $4.06 \mathrm{E}-03$ & 14.6 & $6.31 \mathrm{E}-04$ \\
\hline$c y p-35 A 5$ & K07C6.5 & 5.6 & $1.46 \mathrm{E}-03$ & 12.8 & $4.54 \mathrm{E}-03$ \\
\hline$c y p-35 A 3$ & K09D9.2 & 2.0 & $3.76 \mathrm{E}-03$ & 11.1 & $4.07 \mathrm{E}-04$ \\
\hline$c y p-35 A 2$ & C03G6.15 & 2.5 & $4.96 \mathrm{E}-02$ & 6.6 & $2.93 \mathrm{E}-03$ \\
\hline$c y p-35 B 1$ & K07C6.4 & 4.4 & $3.86 \mathrm{E}-02$ & 5.4 & $2.17 \mathrm{E}-02$ \\
\hline$c y p-35 B 3$ & K07C6.2 & 23.6 & N/A & 4.7 & N/A \\
\hline$c y p-35 A 4$ & C49G7.8 & 1.0 & 0.887 & 2.6 & 0.0709 \\
\hline$c y p-35 D 1$ & F14H3.10 & 1.0 & 0.764 & 1.9 & $4.72 \mathrm{E}-02$ \\
\hline
\end{tabular}

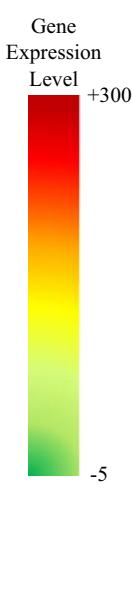

\begin{tabular}{|c|c|c|c|c|c|}
\hline \multirow{2}{*}{$\begin{array}{l}\text { Gene } \\
\text { Name }\end{array}$} & \multirow{3}{*}{$\begin{array}{c}\text { Sequence } \\
\text { Name }\end{array}$} & \multicolumn{2}{|c|}{$5 \mu \mathrm{M} \mathrm{BaP}$} & \multicolumn{2}{|c|}{$20 \mu \mathrm{M}$ BaP } \\
\hline & & Expression & T-test & Expression & T-test \\
\hline & & (fold) & p-value & (fold) & p-value \\
\hline ugt-33 & C35A5.2 & 6.3 & $9.65 \mathrm{E}-05$ & 14.5 & $2.48 \mathrm{E}-03$ \\
\hline ugt-16 & ZC443.6 & 5.2 & $3.96 \mathrm{E}-04$ & 9.9 & $8.04 \mathrm{E}-05$ \\
\hline ugt-10 & T19H12.11 & 3.3 & 0.056 & 7.4 & $2.14 \mathrm{E}-02$ \\
\hline ugt-41 & F10D2.11 & 3.1 & $1.02 \mathrm{E}-02$ & 6.5 & $2.49 \mathrm{E}-03$ \\
\hline ugt-51 & $\mathrm{C} 03 \mathrm{~A} 7.11$ & 2.9 & $3.26 \mathrm{E}-03$ & 6.5 & $1.11 \mathrm{E}-04$ \\
\hline ugt-14 & $\mathrm{H} 23 \mathrm{~N} 18.2$ & 3.2 & $1.12 \mathrm{E}-02$ & 6.4 & $2.47 \mathrm{E}-03$ \\
\hline ugt-40 & F10D2.5 & 2.5 & $4.47 \mathrm{E}-02$ & 6.3 & $4.64 \mathrm{E}-04$ \\
\hline ugt-9 & $\mathrm{T} 19 \mathrm{H} 12.1$ & 2.6 & $5.12 \mathrm{E}-03$ & 6.2 & $2.90 \mathrm{E}-04$ \\
\hline ugt-8 & $\mathrm{H} 23 \mathrm{~N} 18.3$ & 3.5 & $8.10 \mathrm{E}-03$ & 5.4 & $4.03 \mathrm{E}-04$ \\
\hline ugt-13 & $\mathrm{H} 23 \mathrm{~N} 18.1$ & 2.1 & 0.0606 & 3.8 & $1.70 \mathrm{E}-02$ \\
\hline$u g t-4$ & ZC455.5 & 2.5 & $2.07 \mathrm{E}-02$ & 3.7 & $1.72 \mathrm{E}-02$ \\
\hline ugt-1 & $\mathrm{AC} 3.7$ & 2.3 & $4.95 \mathrm{E}-02$ & 2.6 & $3.59 \mathrm{E}-02$ \\
\hline$u g t-36$ & F09G2.6 & 2.0 & 0.0682 & 2.5 & $3.56 \mathrm{E}-02$ \\
\hline$u g t-22$ & C08F11.8 & 1.5 & 0.0928 & 2.3 & $1.03 \mathrm{E}-02$ \\
\hline ugt-5 & ZC455.6 & 3.0 & $3.08 \mathrm{E}-02$ & 2.2 & $4.99 \mathrm{E}-02$ \\
\hline$u g t-52$ & F56B3.7 & 2.2 & $2.97 \mathrm{E}-02$ & 2.1 & $1.52 \mathrm{E}-02$ \\
\hline ugt-53 & T03D3.1 & -1.2 & $2.81 \mathrm{E}-02$ & -2.4 & $1.82 \mathrm{E}-02$ \\
\hline
\end{tabular}

(Fig. 6a, b). The average median survival of cyp-35A2 KO worms exposed to $40 \mu \mathrm{M} \mathrm{BaP}$ did not significantly change in comparison to controls (unexposed) (Fig. 6f). However, the median survival of cyp-35A2 KO worms was significantly longer than wild-type nematodes after exposure to $40 \mu \mathrm{M} \mathrm{BaP}$ (Fig. 6e, f).

The average number of offspring produced by cyp-35A3 $\mathrm{KO}$ worms to $\mathrm{BaP}$ was significantly lower compared to wildtype nematodes in the presence or absence of $\mathrm{BaP}$ exposure (Fig. 6a, c). On the other hand, there was no significant change in the average cumulative number of viable larvae between the control (unexposed) and BaP-exposed cyp$35 A 3 \mathrm{KO}$ nematodes (Fig. 6c). Also, the median survival did not differ in cyp-35A3 $\mathrm{KO}$ nematodes after exposure to 0 or $40 \mu \mathrm{M} \mathrm{BaP}$ (Fig. 6g); however, compared to wild-type nematodes their median survival after exposure to $40 \mu \mathrm{M}$ BaP was significantly extended (Fig. 6e, g).

The average cumulative reproductive performance of cyp-35A5 worms exposed to BaP did not significantly differ to wild-type nematodes (Fig. 6a, d). The median survival of BaP-exposed cyp-35A5 KO nematodes was, however, significantly extended compared to controls (unexposed) (Fig. 6h), which was also significantly extended compared to wild-type nematodes (Fig. 6e, h). Due to the internal hatching of the progeny, all nematodes 
Fig. 5 Maximum likelihood cladogram showing the relationships between the different CYP proteins of C. elegans: 10 CYP-35's (red), other significantly ( $t$ test, $p \leq 0.05, n=3$ ) upregulated CYP's (orange), and the significantly ( $t$ test, $p \leq 0.05$ ) down-regulated CYP's (yellow), in Homo sapiens: CYP1's (blue), the CYP2C's (purple), and others (green). The tree was generated using the MEGA software, version 7.0.26 (colour figure online)

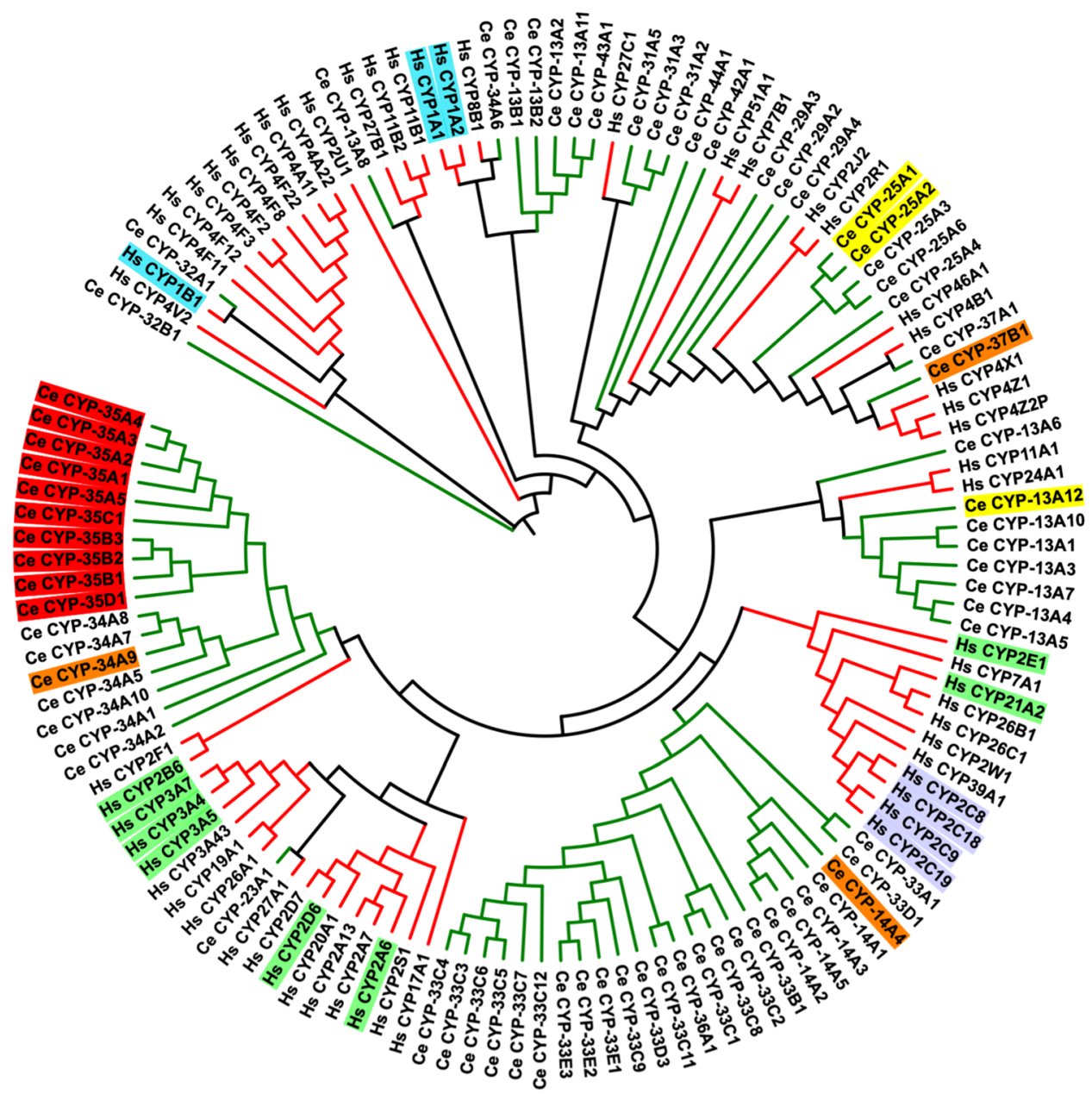

C. elegans gene

Homo sapiens gene

Homo sapiens CYP1A1, CYP1A2, and CYP1B1

C. elegans 10 CYP-35's

Homo sapiens CYP2C8, CYP2C9, CYP2C18 and CYP2C19

upregulated CYP's

Homo sapiens other drug

C. elegans significantly downregulated CYP's metabolism related CYP's of the cyp-35Al KO strain were dead by day 4 (Supplementary 10) (Fig. 7).

\section{Discussion}

\section{Physiological endpoints in C. elegans an organism which lacks the classical CYP1 enzymes}

The effects on key physiological endpoints underlines the notion that $\mathrm{BaP}$ induces substantial toxicological effects on C. elegans despite the fact that it lacks the CYP1 enzymes.
Previous research focusing on the toxicity effects of $\mathrm{BaP}$ on C. elegans used the aqueous media (Sese et al. 2009; Ura et al. 2002; Haegerbaeumer et al. 2018). Our plate-based dosing method also revealed the significant reduction in reproductive capacity and life span observed in C. elegans exposed to $\mathrm{BaP}$, and therefore, this aligns, in general, with previous reports.

\section{Genotoxicity in C. elegans}

The existence of DNA strand breaks indicates the presence of a genotoxic potential. The alkaline single-cell 

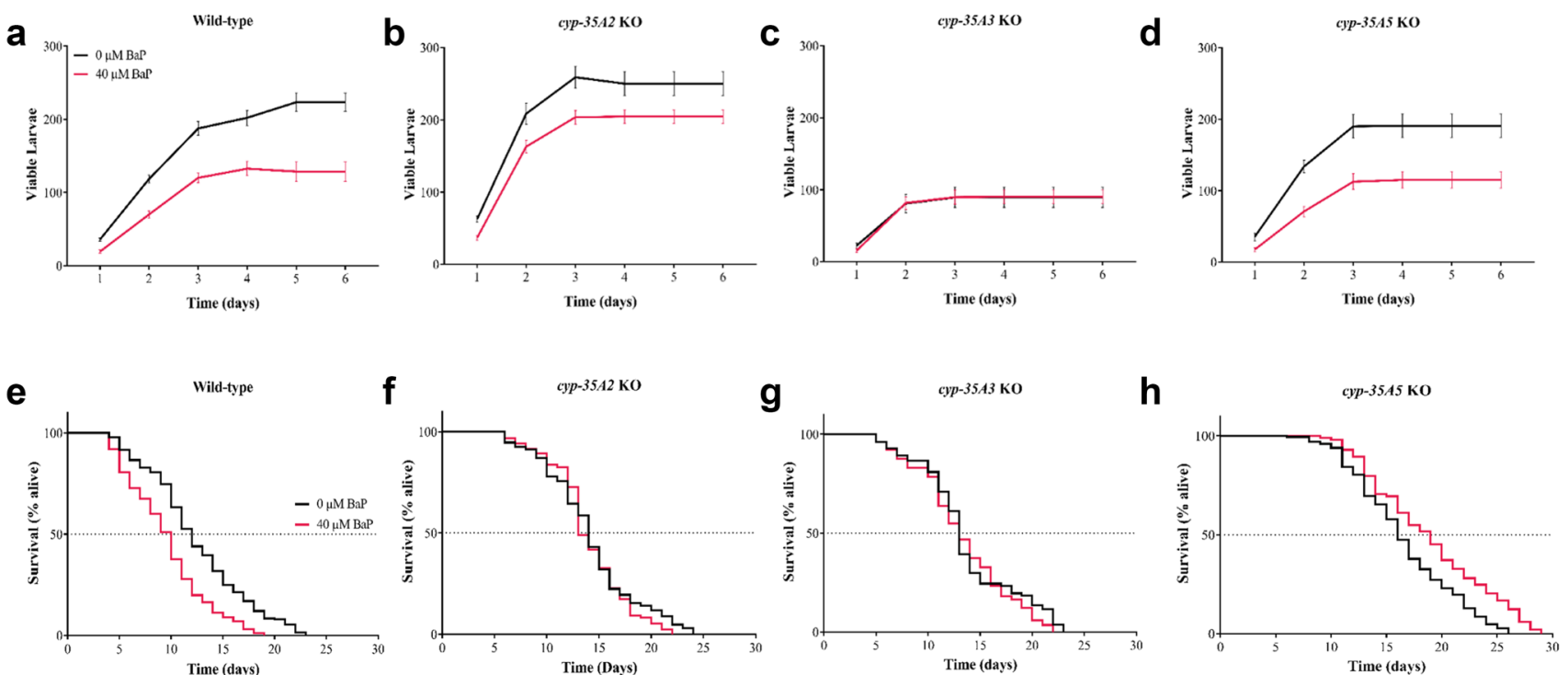

Fig. 6 Brood size and percentage survival of wild-type C. elegans and cyp-35 knockout (KO) strains that were exposed to $\mathrm{BaP}(0$ and $40 \mu \mathrm{M})$. a-d Wild-type C. elegans and cyp-35 knockout (KO) strains were exposed to $\mathrm{BaP}(0$ and $40 \mu \mathrm{M})$ for 8 days, and the average daily number of viable larvae was counted and cumulatively added during the egg laying phase, i.e., 6 days (starting at day 4 from L1) and are labelled $1-6$ on the graphs. The number of viable larvae was counted

every $24 \mathrm{~h}$. Error bars represent SEM. Statistical analysis was performed using a two-way ANOVA, followed by a Sidak's multiple comparisons test, $n=24$ per condition. $\mathbf{e}-\mathbf{h}$ The worms were scored every $24 \mathrm{~h}$ until all worms were dead. Statistical analysis was performed using the log-rank (Mantel-Cox) test, $n=200$ per BaP concentration per strain. All BaP doses contained DMSO (0.1\% v/v)

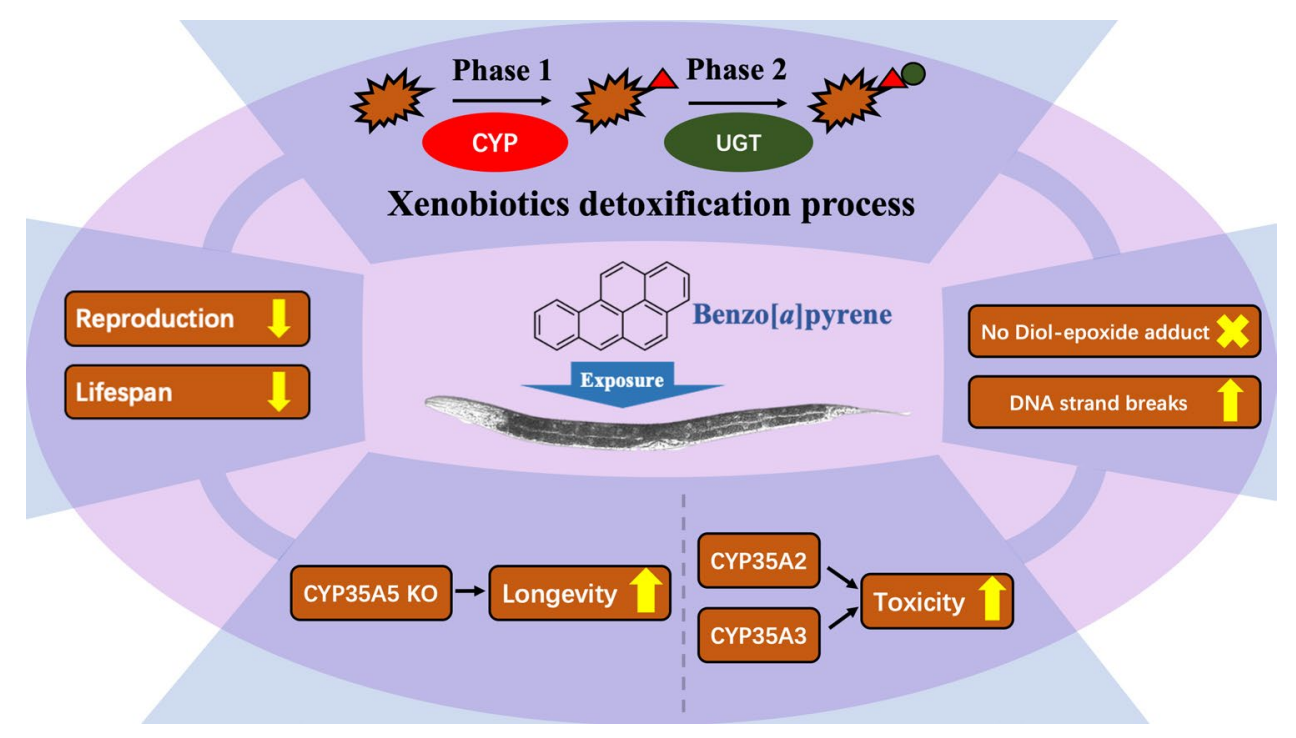

Fig. 7 Summary of the molecular genetic and physiological responses of $C$. elegans exposed to $\mathrm{BaP}$ based on our research. The physiological end points of the wild-type animals showed the significant reduction of reproduction and lifespan. The global transcriptomic analysis demonstrated that the cyp and ugt families were involved in xenobiotics detoxification process. The assessment of

electrophoresis, conventionally referred to as the alkaline comet assay, was utilised on cells dissociated from wildtype $C$. elegans exposed to $\mathrm{BaP}$. The comet assay displayed genotoxicity confirmed an increase in DNA damage (comet) although no BaP-derived DNA adducts (i.e., dG- $N^{2}$-BPDE) were detectable by ${ }^{32} \mathrm{P}$-postlabelling. The physiological measurements on KO strains revealed potential candidates which induce $\mathrm{BaP}$ toxicity and contribute to longevity

a 3-fold increased DNA damage in nematodes exposed to $40 \mu \mathrm{M} \mathrm{BaP}$, a response which was similar to the data reported previously in our laboratory (Imanikia et al. 2016). 
Others have demonstrated that the comet assay can be modified with FPG which increases the sensitivity and specificity in mammalian systems (Speit et al. 2004), and the results obtained here suggested FPG addition improved the sensitivity of the comet assay but were inconclusive regarding BaP's link to oxidative stress. The DNA damage identified here contradict the results of a previous investigation which didn't detect DNA lesions of BaP exposed nematodes using a qPCR assay in aqueous media (Leung et al. 2010).

Interestingly, the ${ }^{32} \mathrm{P}$-postlabelling technique was not able to detect the presence of dG- $N^{2}$-BPDE adducts in wild-type C. elegans exposed to BaP. Although the radical cation (Cavalieri and Rogan 1985; Devanesan et al. 1996) and o-quinone pathways (Penning 2014) for BaP lead to radical-DNA interaction and DNA depurination but their role in $\mathrm{BaP}$ carcinogenesis in C. elegans was beyond the scope of the present study and other techniques such as mass-spectrometry might be required to explore whether different forms of $\mathrm{BaP}$ metabolites generate other types of DNA adducts.

\section{Transcriptional analysis of $C$. elegans exposed to BaP}

RNA-seq is a high-throughput assay which enabled the identification of transcriptomic changes in response to $\mathrm{BaP}$ exposure. The assay revealed that the 312 highly responsive transcripts were dominated by the cyp-35's and ugt's families with subsequent gene ontology analysis highlighting oxidation-reduction processes (GO:0055114), transferase activity (GO:0016758), and response to xenobiotic stimulus (GO:0009410), among others. The cyp-35s are thought to be part of the first stage xenobiotic detoxification response in $C$. elegans and were shown to be induced by $\beta$-naphthoflavone, PCB52, atrazine and lansoprazole. (Menzel et al. 2001, 2005, 2007; Lindblom and Dodd 2006; Harlow et al. 2018). $\mathrm{BaP}$ is metabolised in Homo sapiens mainly by the action of CYP1's (CYP1A1, CYP1A2, and CYP1B1) (Shimada et al. 1997; Gotoh 1998; Xue and Warshawsky 2005; Shimada 2006; Luch and Baird 2010). However, members of the lessknown CYP2 sub- family have been shown to metabolise $\mathrm{BaP}$ as well, namely CYP2C8, CYP2C9, CYP2C18, and CYP2C19 (Guengerich and Shimada 1992; Bauer et al. 1995; Sulc et al. 2016). However, inspection of the maximum likelihood tree derived from $C$. elegans and human CYP protein revealed no close CYP1 and CYP2C sequence homologs in the nematode. Besides, the protein sequence alignment between CYP-35A1 (P04798) and CYP1A1 (O02627) by Clustal Omega revealed an identity score of only $21 \%$. The CYP-35s protein structure is at this point not unavailable, and although the structure of human CYP2A6 (PDB ID: 2FDV) is available, the sequence shares an identity of only $25 \%$ sequence with C.elegans CYP-35A1. To what extent the nematode CYP-35s can compensate or substitute the function of human CYP1 and CYP2C is at present not known.

Phase 2 metabolism comprises the detoxification reactions of xenobiotic metabolism, and UGT enzymes are a key player in this process. There are at least 72 genes that code for UGT-like proteins in C. elegans (Lindblom and Dodd 2006), 16 of which were shown to be up-regulated by BaP exposure. In humans, UGTs have been identified to play a role in the BaP detoxification process, which implies that nematode UGTs may have a similar function (Dellinger et al. 2006; Zhang et al. 2013a; Vergara et al. 2020).

\section{Physiological endpoints in mutant C. elegans}

Five C. elegans cyp-35 knock-out strains were selected and changes in the physiological end points evaluated upon exposure to BaP. Due to worm bagging of cyp-35Al KO nematodes, the brood size data as well as its life span data were only available for 4 days which rendered them unsuitable to investigate their role in BaP metabolism. C. elegans lacking cyp-35A3 were characterised by an absence of a BaP-induced increase in toxicity, suggesting that cyp-35A3 might play an important role in $\mathrm{BaP}$ metabolism. Previous reports have linked cyp-35Al and cyp-35A3 to lipid metabolism (Aarnio et al. 2011; Zhang et al. 2013a, b; Imanikia et al. 2015), indeed, animals lacking another fat metabolising gene (fat-3) displayed a similar abnormal egg-laying behaviour (Lesa et al. 2003; Reisner et al. 2011). The nematodes with a cyp-35A2 or cyp-35A3 mutation exhibited no alteration in median life span after BaP exposure. Taken together this suggests that cyp-35A1, cyp-35A2 and cyp-35A3 are required to initiate the toxic effects of $\mathrm{BaP}$.

$\mathrm{BaP}$ even extended the life span of cyp-35A5 deletion mutant, which is the first report of its involvement in longevity in C. elegans. Previous studies demonstrated that the RNAi of cyp-35A5 resulted in a lower fat content phenotype (Aarnio et al. 2011). Imanikia et al. (2016) stated that the expression of cyp-35A5 and daf-16 were upregulated in fat-5; cyp-35A2 double thereby providing a tentative link between these two genes, where $d a f-16$ serves important stress responsive functions and regulate longevity (Barsyte et al. 2001; Garsin et al. 2003; Mendenhall et al. 2006; Shore and Ruvkun 2013). Furthermore, life span was prolonged by an additional 3 days when the cyp-35A5 mutant was exposed to $\mathrm{BaP}$. This extended longevity might be triggered by the activation of alternative CYPs which contributes to longevity through the clearance of toxins generated by endogenous processes, such as metabolism as well as lipophilic by-products (Gems and McElwee 2005). 


\section{Conclusion and future perspectives}

Overall, this study demonstrates that the exposure to $\mathrm{BaP}$ significantly affects $C$. elegans, including the physiological, genotoxic and transcriptional levels, notably despite the absence of a CYP1 homolog. The highly responsive cyp-35 genes play a central role in regulating the $\mathrm{BaP}$ biotransformation response and appear to be a key player in the hitherto uncharacterised metabolic pathway of $\mathrm{BaP}$ in C. elegans. It is suggested that further genotoxic assays are performed and C.elegans CYP-35 antibodies raised to pinpoint the specificity and interplay of the cyp-35 family in the worm's response to $\mathrm{BaP}$.

Acknowledgements We acknowledge funding through King's College London (to SRS) and thank the King's Genomics Centre for access to equipment. Yuzhi Chen was funded by the King's-China Scholarship Council scheme (201808060084).

Author contributions MA and SRS designed the experiments, with additional input from VMA. MA conducted the experiments except for ${ }^{32} \mathrm{P}$-postlabeling which was performed by VMA. MA and YC analysed the data. YC and SRS wrote the manuscript with additional refinement by VMA.

Funding Yuzhi Chen was funded by the King's-China Scholarship Council scheme (201808060084).

Availability of data and materials The datasets generated during and/ or analyses during the current study are available via GEO accession number GSE152257.

Code availability Not applicable.

\section{Compliance with ethical standards}

Conflict of interest The author(s) declare no potential conflicts of interest with respect to the research, authorship, and/or publication of this article.

Ethical approval Not applicable.

Consent to participate Not applicable.

Consent to publication Not applicable.

Open Access This article is licensed under a Creative Commons Attribution 4.0 International License, which permits use, sharing, adaptation, distribution and reproduction in any medium or format, as long as you give appropriate credit to the original author(s) and the source, provide a link to the Creative Commons licence, and indicate if changes were made. The images or other third party material in this article are included in the article's Creative Commons licence, unless indicated otherwise in a credit line to the material. If material is not included in the article's Creative Commons licence and your intended use is not permitted by statutory regulation or exceeds the permitted use, you will need to obtain permission directly from the copyright holder. To view a copy of this licence, visit http://creativecommons.org/licenses/by/4.0/.

\section{References}

Aarnio V, Lehtonen M, Storvik M et al (2011) Caenorhabditis elegans mutants predict regulation of fatty acids and endocannabinoids by the CYP-35A gene family. Front Pharmacol 2:12. https://doi. org/10.3389/fphar.2011.00012

Albert RE, Miller ML, Cody T et al (1991) Benzo[a]pyrene-induced skin damage and tumor promotion in the mouse. Carcinogenesis 12(7):1273-1280. https://doi.org/10.1093/carcin/12.7.1273

Alexandrov LB, Ju YS, Haase K et al (2016) Mutational signatures associated with tobacco smoking in human cancer. Science 354(6312):618-622. https://doi.org/10.1126/science.aag0299

Arlt VM, Stiborová M, Henderson CJ et al (2008) Metabolic activation of benzo[a]pyrene in vitro by hepatic cytochrome $\mathrm{P} 450$ contrasts with detoxification in vivo: experiments with hepatic cytochrome P450 reductase null mice. Carcinogenesis 29(3):656-665. https ://doi.org/10.1093/carcin/bgn002

Arlt VM, Poirier MC, Sykes SE et al (2012) Exposure to benzo[a] pyrene of Hepatic Cytochrome P450 Reductase Null (HRN) and P450 Reductase Conditional Null (RCN) mice: detection of benzo[a]pyrene diol epoxide-DNA adducts by immunohistochemistry and 32P-postlabelling. Toxicol Lett 213(2):160-166. https://doi.org/10.1016/j.toxlet.2012.06.016

Barsyte D, Lovejoy DA, Lithgow GJ (2001) Longevity and heavy metal resistance in $d a f-2$ and age-1 long-lived mutants of Caenorhabditis Elegans. FASEB J 15(3):627-634. https://doi. org/10.1096/fj.99-0966com

Bauer E, Guo Z, Ueng Y-F et al (1995) Oxidation of benzo[a]pyrene by recombinant human cytochrome P450 enzymes. Chem Res Toxicol 8:136-142. https://doi.org/10.1021/tx00043a018

Bentley DR, Balasubramanian S, Swerdlow HP et al (2008) Accurate whole human genome sequencing using reversible terminator chemistry. Nature 456:53-59. https://doi.org/10.1038/natur e07517

Brand W, Boersma MG, Bik H et al (2010) Phase II metabolism of hesperetin by individual UDP- glucuronosyltransferases and sulfotransferases and rat and human tissue samples. Drug Metab Dispos 38:617-625. https://doi.org/10.1124/dmd.109.031047

Casale GP, Singhal M, Bhattacharya S et al (2001) Detection and quantification of depurinated benzo[a]pyrene-adducted DNA bases in the urine of cigarette smokers and women exposed to household coal smoke. Chem Res Toxicol 14:192-201. https:// doi.org/10.1021/tx000012y

Cavalieri E, Rogan E (1985) Role of radical cations in aromatic hydrocarbon carcinogenesis. Environ Health Perspect. https://doi. org $/ 10.2307 / 3430000$

Chiang P-C, Means JC (2008) Quantification of benzo[a]pyrene-guanine adducts in in vitro samples by LC tandem mass spectrometry with stable isotope internal standardization. J Liq Chromatogr Relat Technol 31:3169-3193. https://doi.org/10.1080/1082607080 2480180

Culetto E (2000) A role for Caenorhabditis elegans in understanding the function and interactions of human disease genes. Hum Mol Genet 9:869-877. https://doi.org/10.1093/hmg/9.6.869

Dellinger RW, Fang JL, Chen G et al (2006) Importance of UDPglucuronosyltransferase 1A10 (UGT1A10) in the detoxification of polycyclic aromatic hydrocarbons: decreased glucuronidative activity of the UGT1A10139LYS isoform. Drug Metab Dispos 34(6):943-949. https://doi.org/10.1124/dmd.105.009100

Devanesan PD, Ariese F, Jankowiak R et al (1996) Depurinating and stable benzo[a]pyrene-DNA adducts formed in isolated rat liver nuclei. Chem Res Toxicol 9:1113-1116. https://doi.org/10.1021/ tx9600513 
Garsin DA, Villanueva JM, Begun J et al (2003) Long-lived C. elegans daf-2 mutants are resistant to bacterial pathogens. Science 300(5627):1921. https://doi.org/10.1126/science.1080147

Gems D, McElwee JJ (2005) Broad spectrum detoxification: the major longevity assurance process regulated by insulin/IGF-1 signaling? Mech Ageing Dev 126(3):381-387. https://doi.org/10.1016/j. $\operatorname{mad} .2004 .09 .001$

Gotoh O (1998) Divergent structures of Caenorhabditis elegans cytochrome P450 genes suggest the frequent loss and gain of introns during the evolution of nematodes. Mol Biol Evol 15(11):1447-1459. https://doi.org/10.1093/oxfordjournals.molbe v.a025872

Guengerich FP, Shimada T (1992) Roles of human liver cytochrome $\mathrm{P} 4502 \mathrm{C}$ and $3 \mathrm{~A}$ enzymes in the 3-hydroxylation of benzo(a)pyrene. Cancer Res 52:1868-1874

Haegerbaeumer A, Höss S, Heininger P, Traunspurger W (2018) Is Caenorhabditis elegans representative of freshwater nematode species in toxicity testing? Environ Sci Pollut Res 25:2879-2888. https://doi.org/10.1007/s11356-017-0714-7

Hansen SH, Olsen AK, Søderlund EJ, Brunborg G (2010) In vitro investigations of glycidamide-induced DNA lesions in mouse male germ cells and in mouse and human lymphocytes. Mutat Res Genet Toxicol Environ Mutagen 696(1):55-61. https://doi. org/10.1016/j.mrgentox.2009.12.012

Harada H, Kurauchi M, Hayashi R, Eki T (2007) Shortened lifespan of nematode Caenorhabditis elegans after prolonged exposure to heavy metals and detergents. Ecotoxicol Environ Saf 66(3):378 383. https://doi.org/10.1016/j.ecoenv.2006.02.017

Harlow PH, Perry SJ, Stevens AJ, Flemming AJ (2018) Comparative metabolism of xenobiotic chemicals by cytochrome P450s in the nematode Caenorhabditis elegans. Sci Rep 8:1-8. https://doi. org/10.1038/s41598-018-31215-w

Harvey RG, Dai Q, Ran C et al (2005) Syntheses of adducts of active metabolites of carcinogenic polycyclic aromatic hydrocarbons with 2'-deoxyribonucleosides. Polycycl Aromat Compd 25(5):371-391. https://doi.org/10.1080/10406630500447019

IARC (2010) Some non-heterocyclic polycyclic aromatic hydrocarbons and some related exposures. Lyon, France

IARC (2012) Personal habits and indoor combustions. Lyon, France

Imanikia S, Hylands P, Stürzenbaum SR (2015) The double mutation of cytochrome P450's and fatty acid desaturases affect lipid regulation and longevity in C. elegans. Biochem Biophys Rep 2:172-178. https://doi.org/10.1016/j.bbrep.2015.06.007

Imanikia S, Galea F, Nagy E et al (2016) The application of the comet assay to assess the genotoxicity of environmental pollutants in the nematode Caenorhabditis elegans. Environ Toxicol Pharmacol 45:356-361. https://doi.org/10.1016/j.etap.2016.06.020

Jones D, Stringham EG, Babich SL, Candido EPM (1996) Transgenic strains of the nematode $C$. elegans in biomonitoring and toxicology: effects of captan and related compounds on the stress response. Toxicology 17(109):2-3. https://doi.org/10.1016/0300483X(96)03316-1

Kaletta T, Hengartner MO (2006) Finding function in novel targets: $C$. elegans as a model organism. Nat Rev Drug Discov 5:387-398. https://doi.org/10.1038/nrd2031

Kasala ER, Bodduluru LN, Barua CC et al (2015) benzo[ $a]$ pyrene induced lung cancer: role of dietary phytochemicals in chemoprevention. Pharmacol Rep 67(5):996-1009

Koch K, Havermann S, Büchter C, Wätjen W (2014) Caenorhabditis elegans as model system in pharmacology and toxicology: effects of flavonoids on redox-sensitive signalling pathways and ageing. Sci World J. https://doi.org/10.1155/2014/920398

Kucab JE, Zou X, Morganella S et al (2019) A compendium of mutational signatures of environmental agents. Cell 177(4):821-836. https://doi.org/10.1016/j.cell.2019.03.001
Kurita A, Miyauchi Y, Ikushiro S et al (2017) Comprehensive characterization of mouse UDP-glucuronosyltransferase (Ugt) belonging to the Ugt2b subfamily: Identification of Ugt $2 \mathrm{~b} 36$ as the predominant isoform involved in morphine glucuronidation. J Pharmacol Exp Ther 361:199-208. https://doi.org/10.1124/jpet.117.240382

Lai CH, Chou CY, Ch'ang LY et al (2000) Identification of novel human genes evolutionarily conserved in Caenorhabditis elegans by comparative proteomics. Genome Res 10:703-713. https://doi. org/10.1101/gr.10.5.703

Lesa GM, Palfreyman M, Hall DH et al (2003) Long chain polyunsaturated fatty acids are required for efficient neurotransmission in C. elegans. J Cell Sci 116:4965-4975. https://doi.org/10.1242/ jcs.00918

Leung MCK, Goldstone JV, Boyd WA et al (2010) Caenorhabditis elegans generates biologically relevant levels of genotoxic metabolites from aflatoxin B1 but not benzo[ $a]$ pyrene in vivo. Toxicol Sci 118(2):444-453. https://doi.org/10.1093/toxsci/kfq295

Lindblom TH, Dodd AK (2006) Xenobiotic detoxification in the nematode Caenorhabditis elegans. J Exp Zool Part A Comp Exp Biol 305(9):720-730. https://doi.org/10.1002/jez.a.324

Luch A, Baird WM (2010) 14.06-carcinogenic polycyclic aromatic hydrocarbons. In: McQueen CABT-CT (ed) Comprehensive toxicology, 2nd edn. Elsevier, Oxford, pp 85-123

Meier B, Cooke SL, Weiss J et al (2014) C. elegans whole-genome sequencing reveals mutational signatures related to carcinogens and DNA repair deficiency. Genome Res. https://doi. org/10.1101/gr.175547.114

Mendenhall AR, LaRue B, Padilla PA (2006) Glyceraldehyde3-phosphate dehydrogenase mediates anoxia response and survival in Caenorhabditis elegans. Genetics 174(3):1173-1187. https://doi.org/10.1534/genetics.106.061390

Menzel R, Bogaert T, Achazi R (2001) A systematic gene expression screen of Caenorhabditis elegans cytochrome P450 genes reveals CYP35 as strongly xenobiotic inducible. Arch Biochem Biophys 395(2):158-168. https://doi.org/10.1006/ abbi.2001.2568

Menzel R, Rödel M, Kulas J, Steinberg CEW (2005) CYP35: xenobiotically induced gene expression in the nematode Caenorhabditis elegans. Arch Biochem Biophys 438(1):93-102. https://doi. org/10.1016/j.abb.2005.03.020

Menzel R, Yeo HL, Rienau S et al (2007) Cytochrome P450s and short-chain dehydrogenases mediate the toxicogenomic response of PCB52 in the Nematode Caenorhabditis elegans. J Mol Biol 370(1):1-13. https://doi.org/10.1016/j.jmb.2007.04.058

Metsalu T, Vilo J (2015) ClustVis: a web tool for visualizing clustering of multivariate data using Principal Component Analysis and heatmap. Nucleic Acids Res 43:W566-W570. https://doi. org/10.1093/nar/gkv468

NRC (2000) Scientific frontiers in developmental toxicology and risk assessment: board on environmental studies and toxicology. Natl Acad Press, Washington. https://doi.org/10.17226/9871

Penning TM (2014) Human aldo-keto reductases and the metabolic activation of polycyclic aromatic hydrocarbons. Chem Res Toxicol 27:1901-1917. https://doi.org/10.1021/tx500298n

Phillips DH (1999) Polycyclic aromatic hydrocarbons in the diet. Mutat Res Genet Toxicol Environ Mutagen 443(1-2):139-147. https:// doi.org/10.1016/S1383-5742(99)00016-2

Phillips DH, Arlt VM (2007) The ${ }^{32}$ P-postlabeling assay for DNA adducts. Nat Protoc 2:2772-2781. https://doi.org/10.1038/nprot .2007 .394

Phillips DH, Arlt VM (2020) 32P-postlabeling analysis of DNA adducts BT-molecular toxicology protocols. In: Keohavong P, Singh KP, Gao W (eds) Molecular toxicology protocols. Springer US, New York, pp 291-302

Polak N, Read DS, Jurkschat K et al (2014) Metalloproteins and phytochelatin synthase may confer protection against zinc oxide 
nanoparticle induced toxicity in Caenorhabditis elegans. Comp Biochem Physiol C Toxicol Pharmacol 160:75-85. https://doi. org/10.1016/j.cbpc.2013.12.001

Prakash C, Zuniga B, Song CS et al (2015) Nuclear receptors in drug metabolism, drug response and drug interactions. Nucl Recept Res 2:101178. https://doi.org/10.11131/2015/101178

Rajini PS, Melstrom P, Williams PL (2008) A comparative study on the relationship between various toxicological endpoints in $\mathrm{Cae}$ norhabditis elegans exposed to organophosphorus insecticides. J Toxicol Environ Health Part A Curr Issues 71:1043-1050. https ://doi.org/10.1080/15287390801989002

Reed L, Mrizova I, Barta F et al (2018) Cytochrome b5impacts on cytochrome $\mathrm{P} 450$-mediated metabolism of benzo[a]pyrene and its DNA adduct formation: studies in hepatic cytochrome b5/P450 reductase null (HBRN) mice. Arch Toxicol 92:1625-1638. https ://doi.org/10.1007/s00204-018-2162-7

Reisner K, Lehtonen M, Storvik M et al (2011) Trans fat diet causes decreased brood size and shortened lifespan in Caenorhabditis elegans delta-6-desaturase mutant fat-3. J Biochem Mol Toxicol 25(5):269-279. https://doi.org/10.1002/jbt.20386

Riddle DL, Blumenthal T, Meyer BJ, Priess JR (1997) Introduction to C. elegans. In: Riddle DL, Blumenthal T, Meyer BJ, Priess JR (eds). Cold Spring Harbor (NY)

Rogan EG, Devanesan PD, RamaKrishna NVS et al (1993) Identification and quantitation of benzo[ $a]$ pyrene -DNA adducts formed in mouse skin. Chem Res Toxicol 6(3):356-363. https://doi. org/10.1021/tx00033a017

Sese BT, Grant A, Reid BJ (2009) Toxicity of polycyclic aromatic hydrocarbons to the nematode Caenorhabditis elegans. J Toxicol Environ Health Part A Curr Issues 72(19):1168-1180. https://doi. org/10.1080/15287390903091814

Shimada T (2006) Xenobiotic-metabolizing enzymes involved in activation and detoxification of carcinogenic polycyclic aromatic hydrocarbons. Drug Metab Pharmacokinet 21:257-276. https:// doi.org/10.2133/dmpk.21.257

Shimada T, Gillam EMJ, Sutter TR et al (1997) Oxidation of xenobiotics by recombinant human cytochrome P450 1B1. Drug Metab Dispos 25(5):617-622

Shore DE, Ruvkun G (2013) A cytoprotective perspective on longevity regulation. Trends Cell Biol 23(9):409-420. https://doi. org/10.1016/j.tcb.2013.04.007

Speit G, Schütz P, Bonzheim I et al (2004) Sensitivity of the FPG protein towards alkylation damage in the comet assay. Toxicol Lett 146(2):151-158. https://doi.org/10.1016/j.toxlet.2003.09.010

Steinberg CEW, Stürzenbaum SR, Menzel R (2008) Genes and environment-striking the fine balance between sophisticated biomonitoring and true functional environmental genomics. Sci Total Environ 400(1-3):142-161. https://doi.org/10.1016/j.scito tenv.2008.07.023
Šulc M, Indra R, Moserová M et al (2016) The impact of individual cytochrome P450 enzymes on oxidative metabolism of benzo[a] pyrene in human livers. Environ Mol Mutagen 57:229-235. https ://doi.org/10.1002/em.22001

Swain SC, Keusekotten K, Baumeister R, Sturzenbaum SR (2004) C. elegans metallothioneins: new insights into the phenotypic effects of cadmium toxicosis. J Mol Biol 341(4):951-959

Ura K, Kai T, Sakata S et al (2002) Aquatic acute toxicity testing using the nematode Caenorhabditis elegans. J Health Sci 9(10):12851290. https://doi.org/10.1248/jhs.48.583

Vergara AG, Watson CJW, Chen G, Lazarus P (2020) UDP-glycosyltransferase $3 \mathrm{~A}$ metabolism of polycyclic aromatic hydrocarbons: potential importance in aerodigestive tract tissues. Drug Metab Dispos 48(3):160-168. https://doi.org/10.1124/dmd.119.089284

Volkova NV, Meier B, González-Huici V et al (2020) Mutational signatures are jointly shaped by DNA damage and repair. Nat Commun. https://doi.org/10.1038/s41467-020-15912-7

Wang L, Xu W, Ma L et al (2017) Detoxification of benzo[a]pyrene primarily depends on cytochrome P450, while bioactivation involves additional oxidoreductases including 5-lipoxygenase, cyclooxygenase, and aldo-keto reductase in the liver. J Biochem Mol Toxicol 31(7):e21902. https://doi.org/10.1002/jbt.21902

Williams PL, Dusenbery DB (1990) Aquatic toxicity testing using the nematode Caenorhabditis elegans. Environ Toxicol Chem 9(10):1285-1290. https://doi.org/10.1002/etc.5620091007

Willis AJ, Indra R, Wohak LE et al (2018) The impact of chemotherapeutic drugs on the CYP1A1-catalysed metabolism of the environmental carcinogen benzo[a]pyrene: effects in human colorectal HCT116 TP53(+/+), TP53(+/-) and TP53(-/-) cells. Toxicology 398-399:1-12. https://doi.org/10.1016/j.tox.2018.02.006

Xue W, Warshawsky D (2005) Metabolic activation of polycyclic and heterocyclic aromatic hydrocarbons and DNA damage: a review. Toxicol Appl Pharmacol 206:73-93. https://doi.org/10.1016/j. taap.2004.11.006

Zhang L, Huang M, Blair IA, Penning TM (2013a) Interception of benzo[ $a]$ pyrene-7,8-dione by UDP glucuronosyltransferases (UGTs) in human lung cells. Chem Res Toxicol 26(10):1570 1578. https://doi.org/10.1021/tx400268q

Zhang Y, Zou X, Ding Y et al (2013b) Comparative genomics and functional study of lipid metabolic genes in Caenorhabditis elegans. BMC Genomics 14:1-13. https://doi. org/10.1186/1471-2164-14-164

Publisher's Note Springer Nature remains neutral with regard to jurisdictional claims in published maps and institutional affiliations. 